\title{
Summer sea breeze, under suppressive synoptic forcing, in a hyper-arid city: Eilat, Israel
}

\author{
Hadas Saaroni ${ }^{1, *}$, Eitan Maza ${ }^{1}$, Baruch Ziv $^{2}$ \\ ${ }^{1}$ Department of Geography and the Human Environment, Tel-Aviv University, POB 39040, Tel Aviv 69978, Israel \\ ${ }^{2}$ The Open University of Israel, 16 Klausner St., Tel-Aviv 61392, Israel
}

\begin{abstract}
Eilat is a hyper-arid city, located at the northern end of the Gulf of Eilat. The summer weather conditions over the region are highly persistent, with offshore northerly winds of 5 to $7 \mathrm{~m} \mathrm{~s}^{-1}$ and a daily maximum temperature of 39 to $40^{\circ} \mathrm{C}$. The relatively cool $\left(\sim 26^{\circ} \mathrm{C}\right)$ sea surface temperature (SST) to the south suggests that a southerly sea breeze would exist in spite of the opposing prevailing northerly winds and the small scale of the sea (10 to $20 \mathrm{~km}$ width). A 6 yr study (1994 to 1999) indicates that the sea breeze develops in only $25 \%$ of the days in July and August. The breeze typically lasts for about 4 to $6 \mathrm{~h}$, with wind speeds of only 1 to $3 \mathrm{~m} \mathrm{~s}^{-1}$. A synoptic analysis indicates that the prevailing pattern, the Persian Trough, exists on $99 \%$ of the days, but on the 'breeze' days the synoptic-scale suppressive pressure gradient was $38 \%$ weaker. In 4 cases for which the synoptic scale gradient was negligible, the speed of the sea breeze reached 6 to $7.2 \mathrm{~m} \mathrm{~s}^{-1}$, indicating the effectiveness of the Gulf of Eilat as a source of sea breeze. A seasonal decrease of $49 \%$ found in breeze occurrence between July and August is explained by both a seasonal increase in the pressure gradient and a decrease in solar radiation. The daily maximum temperature on the 'breeze' days was $1.2^{\circ} \mathrm{C}$ lower and the minimum relative humidity was $4 \%$ higher, whereas the heat stress regime did not differ significantly. An increase in the wet bulb temperature that was found at the same time implies that the efficiency of evaporative cooling devices is reduced when sea breeze exists. Our study suggests that in coastal areas subjected to hot and dry conditions, where the prevailing synoptic winds oppose the sea breeze, the effectiveness of the sea breeze depends strongly on the inter-diurnal variations of the synoptic pressure gradient.
\end{abstract}

KEY WORDS: Sea breeze $\cdot$ Synoptic forcing $\cdot$ Hyper-arid city $\cdot$ Heat stress $\cdot$ Eilat $\cdot$ Red Sea

\section{INTRODUCTION}

The sea breeze has important environmental implications for comfort conditions and air pollution, in particular under hot conditions (e.g. Melas 2000). The net relieving effect of a sea breeze, such as those that prevail in subtropical regions, depends on the balance between 2 opposing contributions to heat stress: cooling, which reduces heat stress, and moisturizing, which increases it.

Sea breeze circulations are well developed during the summer around $30^{\circ}$ latitudes due to the high radiation rate there and to the subtropical highs that cause relatively weak pressure gradients and low cloudiness (Oke 1987, Arya 2001). Breezes have been observed and analyzed even on the coasts of relatively small water bodies. Extreme examples are lake breezes found near the northern part of the Dead Sea (Bitan 1977) and Lake Kinneret (Bitan 1981, Alpert et al. 1982), which both have horizontal dimensions of only $\sim 10 \mathrm{~km}$.

An increase in the synoptic gradient or increase in cloudiness may hinder or even cancel the sea breeze. In order to penetrate inland, the sea breeze needs a pressure gradient that supports it or, at least, does not interfere with it (Arritt 1993). For example, the firstdegree factor influencing the lake breeze over Lake Michigan is the synoptic one rather than the local thermal gradient according to Laird et al. (2001), who found a negative correlation between the speed of the 


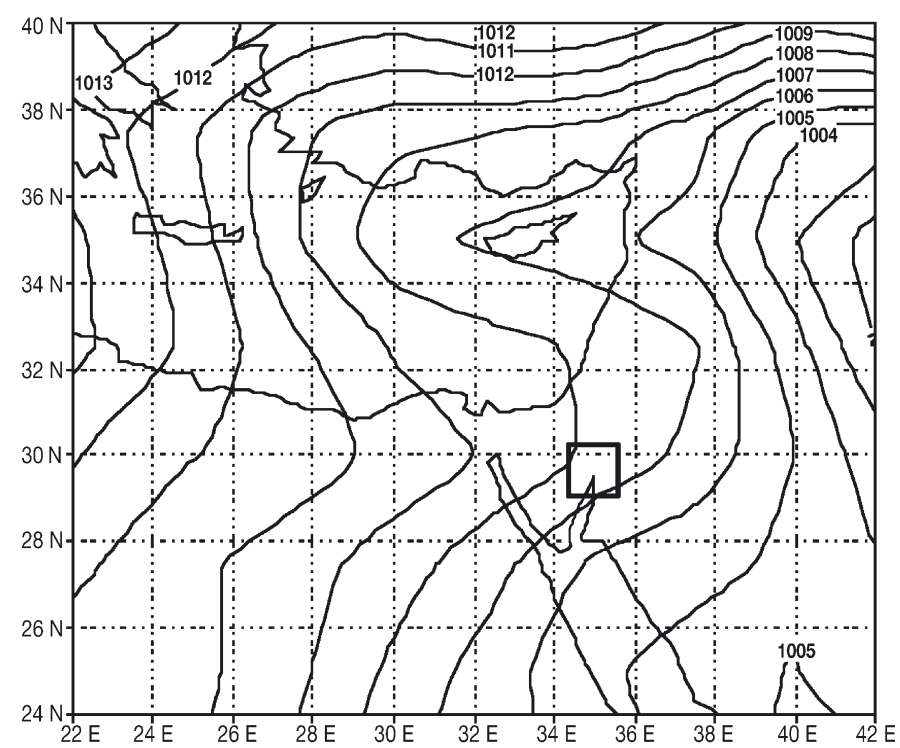

Fig. 1. Long-term mean sea level pressure averaged over 1968-1996 (in hPa units, $1 \mathrm{hPa}$ interval) for July-August (NCEP/NCAR CDAS-1 archive, Kalnay et al. 1996, Kistler et al. 2001). Box denotes study area

opposing synoptic wind and the occurrence of the sea breeze. The synoptic factor was also found to be dominant in Athens, where a weakening in the summer Etesian wind is a necessary condition for the development of local circulations, such as a sea/land breeze (Melas et al. 1995).

The weather conditions over the Eastern Mediterranean (EM) are highly persistent during the summer season, i.e. June-September, particularly in JulyAugust. The lower levels are dominated by the socalled 'Persian Trough' (Alpert et al. 1990, Bitan \& Saaroni 1992, Saaroni \& Ziv 2000), a pressure trough that extends from the Asian Monsoon through the Persian Gulf, along southern Turkey, down to the Aegean Sea. The Persian Trough appears clearly in the average monthly sea level pressure maps during summer, as seen in Fig. 1. As a result, the winds over the EM, i.e. the Etesian winds (e.g. Air Ministry 1962, Metaxas 1977, Prezerakos 1984), flow from the northwest sector. These winds veer north over the southern and eastern parts of Israel due to the influence of the ridge extending from North Africa toward southern Israel (Alpert et al. 1990). They gain strength along the Rift Valley, which is 7 to $10 \mathrm{~km}$ wide, due to the channeling effect (Alpert \& Getenio 1988) of the mountain chains extending along both sides of the region (the Eilat Mountains to the west, up to $1000 \mathrm{~m}$ above sea level [ASL], and the Edom Mountains to the east, up to $1600 \mathrm{~m}$ ASL, Fig. 2) which are oriented south-southwest-north-northwest. The average speed of these winds in the southern part of this region during the daytime is 5 to $7 \mathrm{~m} \mathrm{~s}^{-1}$ in July (Bitan \& Rubin 1994). The Gulf of Eilat, located at the southern tip of the Rift Valley (Fig. 2), is $250 \mathrm{~km}$ long and 10 to $20 \mathrm{~km}$ wide. The existence of lake breezes, noted above, suggests that a sea breeze could be expected in Eilat, blowing from the south, against the synoptic forcing.

The climate of Eilat is hyper-arid, 'BW' according to the Köppen classification. The average daily maximum temperature for July-August is $39.2^{\circ} \mathrm{C}$ (absolute maximum: $47.2^{\circ} \mathrm{C}$ ) and the average relative humidity is only $16 \%$ at 14:00 h local sidereal time (LST) (Bitan \& Rubin 1994, based on 3 hourly observations from 1963 to 1983). The resulting Heat Stress Index (HSI), according to the definition of Thom (1959) and Sohar (1980), exists during these months all day long, and is severe for $7 \mathrm{~h} \mathrm{a}$ day on average. These dry and hot conditions suggest that sea breeze has only a minor effect on the local climate in summer. The sea surface temperature (SST) of the Gulf of Eilat is only $26^{\circ} \mathrm{C}$ (Israel Meteorological Service), implying a 13 to $15^{\circ} \mathrm{C}$ contrast between the Gulf and the temperature above the adjacent land, larger than that existing along the EM coast $\left(\sim 5^{\circ} \mathrm{C}\right)$. This large contrast suggests that Eilat should be subjected to the influence of a sea breeze. The north and northeasterly winds, opposing the sea breeze, dominate all year around and southerly winds are the second most frequent, only during the afternoon hours, with $16 \%$ occurrence at 17:00 h LST in July (Bitan \& Rubin 1994).

The sea breeze along the EM coast and its relationship with the Etesian winds in the summer season, as well as with the topography, were studied and simulated extensively (Doron \& Neumann 1977, Mahrer 1985, Segal et al. 1985, Goldreich et al. 1986, Alpert \& Getenio 1988), but the sea breeze in Eilat, originating from the Red Sea, has not yet been studied. This study

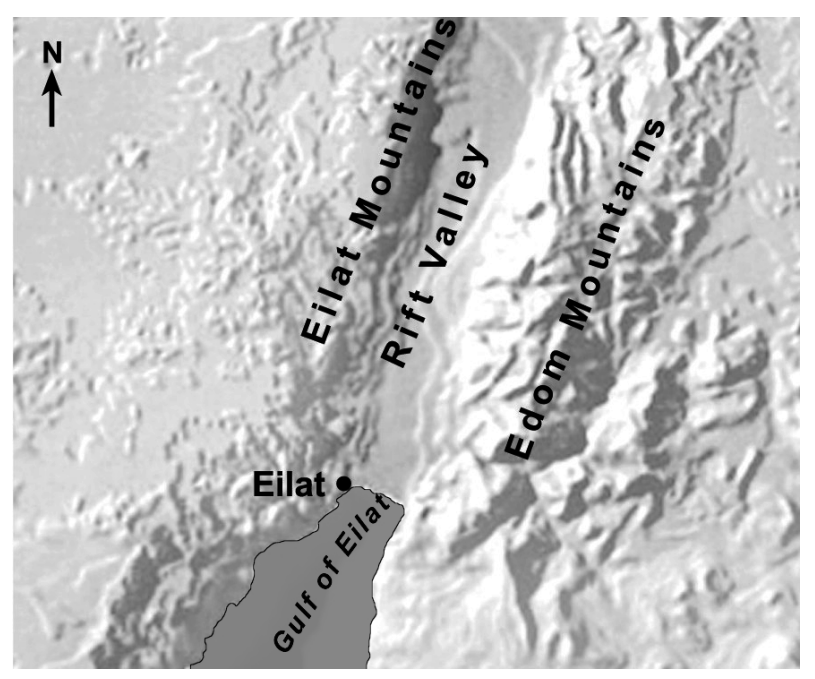

Fig. 2. Region of Eilat, showing the topography 
documents in detail the sea breeze in the summer season in Eilat, evaluates its relationship with synoptic scale factors over the region, and examines its impact on the climatic conditions in this hyper-arid city. The results may be applicable for other geographical regions where severe heat stress conditions are combined with an offshore synoptic scale wind.

\section{METHODOLOGY}

The present study concentrates on the mid-summer months, July and August, the hottest months of the year. Data were taken from the station at Eilat airport, located $2 \mathrm{~km}$ north of the coast. Wind data are available on an hourly basis for the years 1994 to1999, and temperature and relative humidity data only for the years 1996 to1999. Synoptic scale data were taken from the National Center for Environmental Protection/ National Center for Atmospheric Research (NCEP/NCAR) archive (NCEP/ NCAR CDAS-1 archive; Kalnay et al. 1996, Kistler et al. 2001).

Statistical analysis was performed for the winds from the south sector, assuming that they reflect sea breeze. The analysis includes frequency, timing, duration, speed and direction. The effect of the breeze on temperature, humidity and heat stress was derived from a comparison between days on which southerly wind was observed, hereafter 'breeze' days, and days on which no southerly wind was observed, i.e. 'nonbreeze' days. Evaluation of the synoptic factor was done by comparing the 2 groups of days. Correlations between various synoptic factors and the characteristics of the southerly winds were calculated.

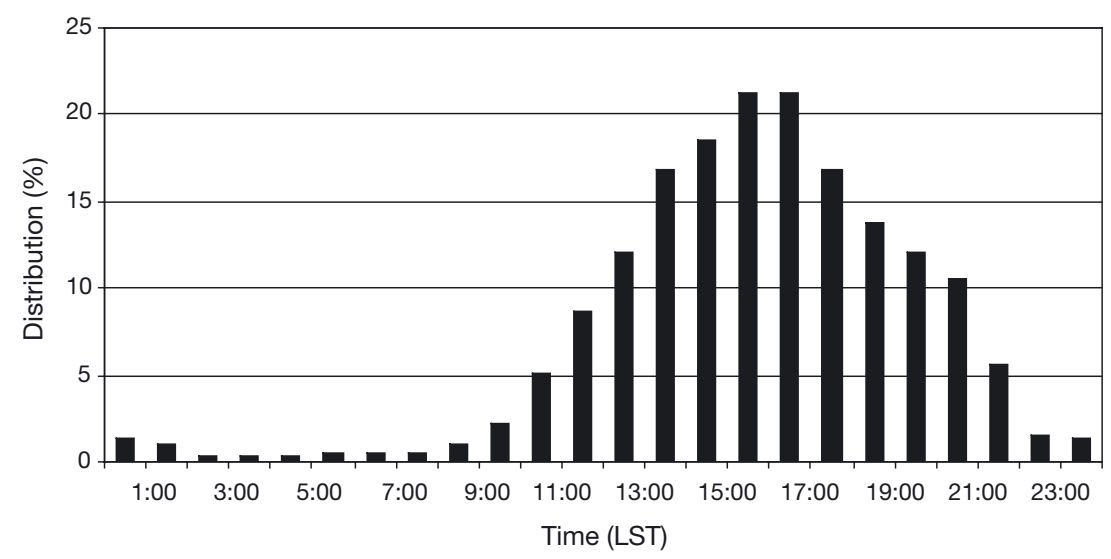

Fig. 3. Diurnal distribution (\%) of southerly winds in Eilat for July-August 1994-1999

\section{RESULTS}

\subsection{Wind regime}

Southerly winds were observed, at least once, on $25 \%$ of the days, but the percentage of hours during which southerly winds were observed was only $7.4 \%$. The diurnal variation in their frequency (Fig. 3) indicates that they were most frequent during the afternoon hours, with a maximum probability of $21 \%$ at 16:00 and 17:00 h LST, and least frequent in the early morning, $0.3 \%$ at 03:00 to 05:00 h LST. Their average starting and ending times were 12:30 and 19:00 $\mathrm{h}$ LST, respectively, and the most frequent duration was 4 to $6 \mathrm{~h}$ (Fig. 4). The diurnal distribution and the timing of the southerly winds support the idea that they can be considered a sea breeze.

The above findings indicate that the sea breeze in Eilat is much shorter and develops later than the sea breeze along the Mediterranean coast, which lasts for about 12 h, between 07:00 and 19:00 h LST (Skibin \& Hod 1979, Goldreich et al. 1986). Only in 6 out of the 95 'breeze' days in Eilat did the southerly wind last for more than 12 h, e.g. up to 22 h on 16 July 1999.

The daily course of the southerly wind component is shown separately for the 'breeze' and the 'non-breeze' days in Fig. 5. The average wind on the 'breeze' days was southerly between 12:30 and 19:00 h LST, with a maximum of $2.0 \mathrm{~m} \mathrm{~s}^{-1}$ at 17:00 h LST, the same time the southerly winds reached their maximum frequency (Fig. 3). This speed is about half of that typifying a sea breeze, 3 to $6 \mathrm{~m} \mathrm{~s}^{-1}$ (Zhong \& Takle 1993) and one-third of the typical EM sea breeze, which is more than $5 \mathrm{~m} \mathrm{~s}^{-1}$ (Goldreich et al. 1986). However, the maximum individual speed was $7.2 \mathrm{~m} \mathrm{~s}^{-1}$, which is 


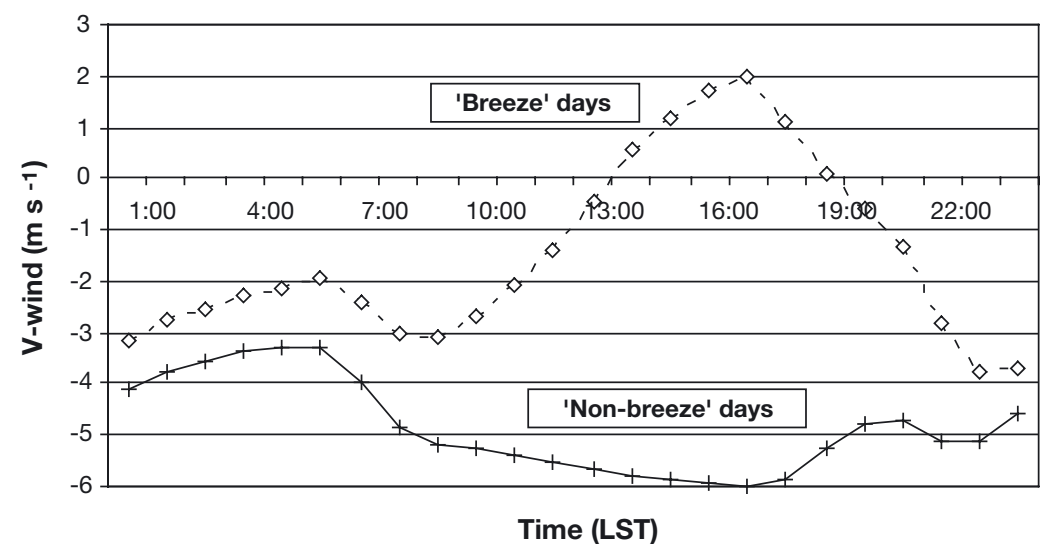

Fig. 5. Daily course of the average V-wind component $\left(\mathrm{m} \mathrm{s}^{-1}\right)$ for July August 1994-1999 for 'breeze' days (dashed lines) and 'non-breeze' days (solid lines) ference between the $32.5^{\circ} \mathrm{N}, 32.5^{\circ} \mathrm{E}$ and $27.5^{\circ} \mathrm{N}, 35^{\circ} \mathrm{E}$ grid points, located to the northwest and the southeast of Eilat. The average difference at 12:00 h UTC (coordinated universal time) was 3.1 and $5.0 \mathrm{hPa}$ for the 'breeze' and the 'non-breeze' days, respectively, in agreement with Fig. 7 . This effect is expressed also by the correlation, -0.43 , found between the duration of the sea breeze and the pressure difference between these grid points. This relationship is further emphasized in the 4 extreme cases, in which southerly wind approached 6.0 to $7.2 \mathrm{~m} \mathrm{~s}^{-1}$. In these 4 cases the average pressure difference was only $1.9 \mathrm{hPa}$.

The inhibiting effect of the pressure gradient over the region on the sea breeze suggests that an intermonthly increase in the pressure gradient can explain the decreasing trend in the occurrence of 'breeze' days from July to August (Section 3.1). Fig. 6 indicates, indeed, a consistent seasonal increase, of over $25 \%$, in the pressure gradient over the region from the last $10 \mathrm{~d}$ period of July toward the end of August that is highly correlated $(\mathrm{R}=-0.93)$ with the occurrence of 'breeze' days. The seasonal decrease in solar radiation of $7.2 \%$ between July and August (Bitan \& Rubin 1994) also explains this decreasing trend.

\subsection{Implications for temperature, humidity and heat stress}

The diurnal course of the average temperature and relative humidity for the 'breeze' and 'non-breeze' days is shown in Fig. 8a. During the morning hours the 'breeze' days were warmer (reaching a $1.7^{\circ} \mathrm{C}$ difference at 08:00 and 09:00 h LST) and drier. The water vapor pressure was $\sim 1.2 \mathrm{hPa}$ lower during the morning hours of the 'breeze' days (Fig. 8b). At 14:00 h LST, the

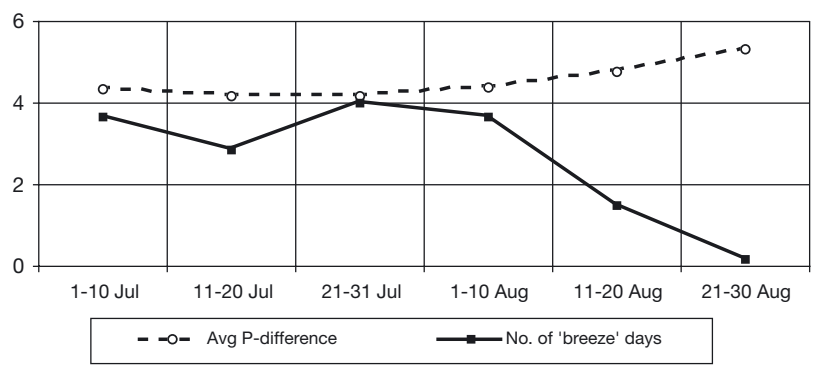

Fig. 6. Seasonal variation, averaged over July-August 1994-1999, in the number of 'breeze' days (solid line) and of pressure $(\mathrm{P})$ difference $(\mathrm{hPa})$ between $32.5^{\circ} \mathrm{N}, 32.5^{\circ} \mathrm{E}$ and

$$
27.5^{\circ} \mathrm{N}, 35^{\circ} \mathrm{E} \text { (dashed line) }
$$

The effect of synoptic-scale pressure gradient on the sea breeze was evaluated by the sea level pressure dif-
An inspection of the NCEP/NCAR data for the study
eriod indicates that on all of the days in the study period the synoptic situation remained similar, i.e. the Persian Trough (except for 1 day, 16 July 1999, in which the region was under a col). However, several differences can be discerned between the 'breeze' and the 'non-breeze' days (Fig. 7). The most prominent is the deepening of the Mediterranean part of the Persian Trough further toward the west during 'breeze' days (Fig. 7a), whereas no significant difference is found over Saudi Arabia, to the east of Eilat. This difference is expressed in a backing of the northwesterly Etesian winds over Israel on the 'breeze' days, implying a weakening of the northwest-southeast pressure gradient over the Gulf of Eilat that suppresses the sea breeze there. 
a

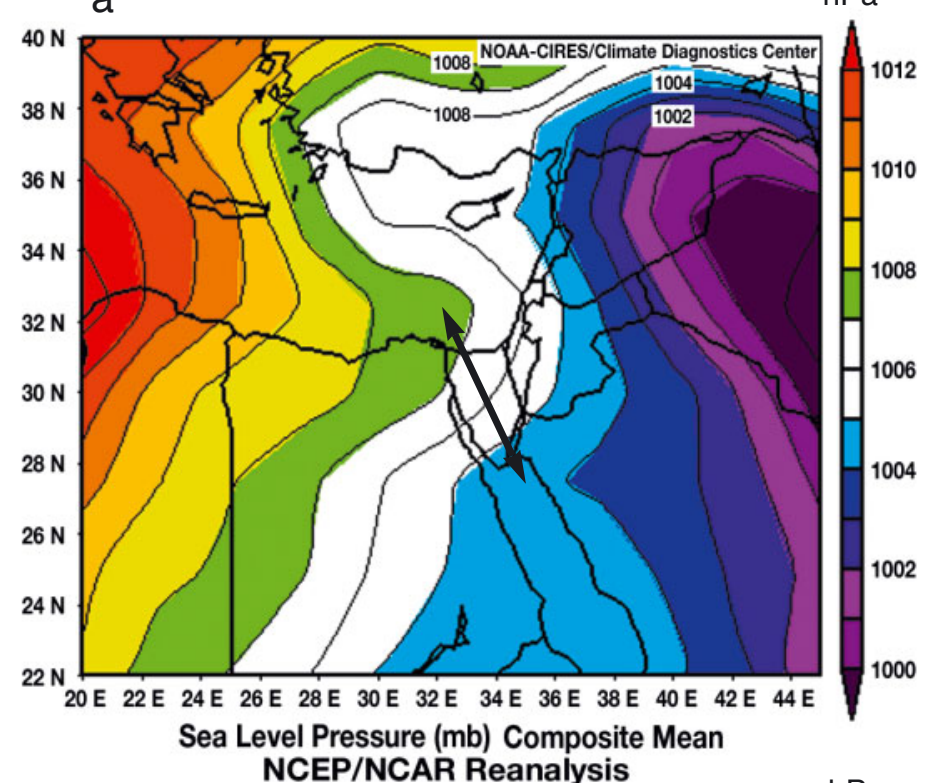

b

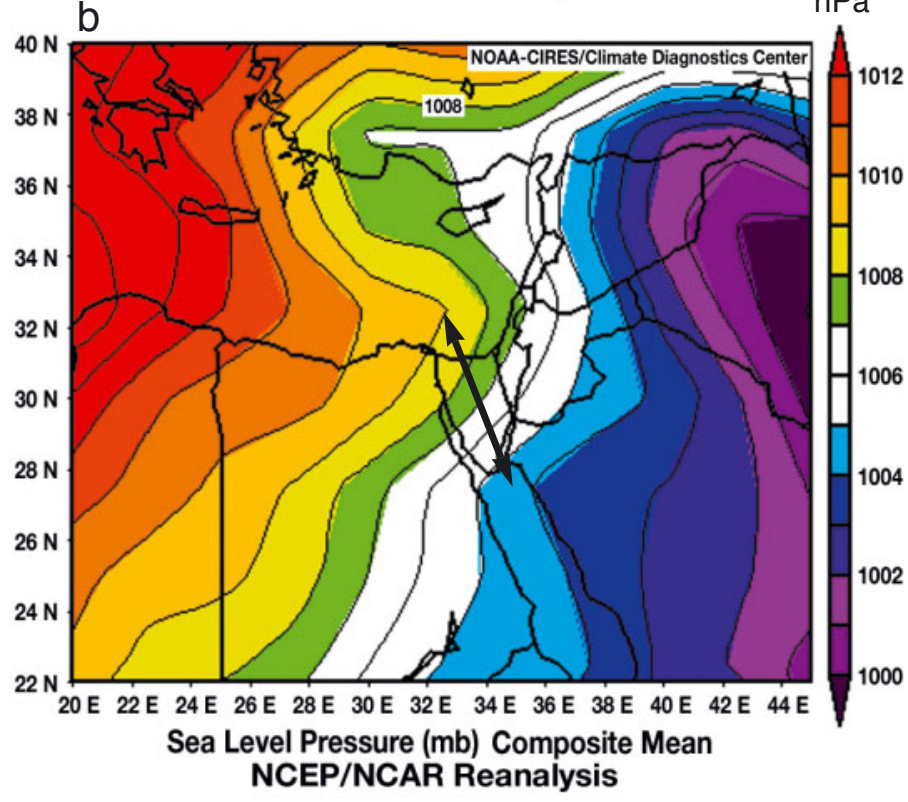

Fig. 7. Average sea level pressure for (a) the 'breeze' days and for (b) the 'non-breeze' days, 12:00 h UTC (coordinated universal time) for the years 1994-1999 (NCEP/NCAR CDAS-1 archive)

time at which the sea breeze began on the majority of the 'breeze' days, the temperature, relative humidity and water vapor pressure differences were reversed. The differences increased gradually until 17:00 to 18:00 $\mathrm{h}$ LST, when the breeze attained its maximum intensity (Fig. 5), when the 'breeze' days were $2.4^{\circ} \mathrm{C}$ cooler and $10 \%$ wetter ( $\sim 5 \mathrm{hPa}$ in water vapor).

The resulting HSI (Fig. 9) on the 'breeze' days was lower between 15:00 and 21:00 h LST, although by not more than $0.4^{\circ} \mathrm{C}$. This low difference can be explained by the cancellation between the cooling and moisturizing effects. It is worth noting that severe heat stress prevailed on both 'breeze' and 'nonbreeze' days for the same period, i.e. $10 \mathrm{~h}$. The only difference is that on the 'non-breeze' days this period lagged behind that for the 'breeze' days by $1 \mathrm{~h}$. This lag results from the combination of higher heat stress observed on 'breeze' days prior to the breeze development (difference of 0.7 to $0.8^{\circ} \mathrm{C}$ between $08: 00$ and 11:00 h LST, Fig. 9) and the relieving effect of the breeze, on the 'breeze' days, later on. The higher heat stress observed for the majority of the daytime hours on the 'breeze' days (the daily average temperature was $0.2^{\circ} \mathrm{C}$ higher) indicates that the synoptic conditions on these days imply that they would be hotter than the 'non-breeze' days. The possible reason for this is discussed in the following section.

In order to focus on the effect produced by the breeze we did a refined comparison, on an hourly basis, of temperature and heat stress (Fig. 10). Each value is averaged separately for the days on which sea breeze was observed at that specific hour (e.g. 18 cases at 12:00 $\mathrm{h} \mathrm{LST}$ and 49 cases at 17:00 $\mathrm{h} \mathrm{LST}$ ) and for the rest of the days. The general pattern is similar, but the differences have almost doubled, so that the temperature and heat stress difference reaches 3.8 and $0.7^{\circ} \mathrm{C}$, respectively, at 19:00 $\mathrm{h} \mathrm{LST}$. It is worth noting that while some relief was achieved by the sea breeze, the wet-bulb temperature was found to be up to $2.3^{\circ} \mathrm{C}$ higher (between 17:00 and 19:00 h LST). At the same time, the dry temperature dropped so that the difference between them was reduced by up to $6^{\circ} \mathrm{C}$. This implies that evaporative cooling, both individual and environmental, loses its effectiveness.

\section{DISCUSSION AND CONCLUSIONS}

The sea breeze in Eilat in the mid-summer months, July-August, was examined for the years 1994 to 1999. A sea breeze would be expected there due to the large sea-land temperature contrast, in spite of the suppressing synoptic-scale persistent northerly winds. Southerly winds were observed on $25 \%$ of the days and regarded as sea breeze. A seasonal decrease, from $34 \%$ in July to $16 \%$ in August, was found. When it occurs, the sea breeze starts around 12:30 h LST and lasts for 4 to $6 \mathrm{~h}$, with a maximum speed of $\sim 2 \mathrm{~m} \mathrm{~s}^{-1}$, which is about one-third of the prevailing northerlies.

The breeze in Eilat is weaker than that of the EM in several aspects: its frequency is smaller $(1 / 4$ of that along the EM) its duration is shorter $(<1 / 2)$ and its speed is lower $(\sim 1 / 3)$. These differences may stem either from the substantial difference in the role of the synopticscale forcing, which supports the sea breeze along the EM coastline but suppresses it in Eilat, or from the rel- 
atively small scale of the Gulf of Eilat. In order to separate between the 2 factors, the synoptic conditions that prevailed when the sea breeze in Eilat was most intense were examined. It was found that the suppres- sive synoptic conditions were significantly weaker than normal on these days, though the pressure gradient still opposed the sea breeze. The average maximum breeze speed for these days $\left(6.6 \mathrm{~m} \mathrm{~s}^{-1}\right)$ indicates
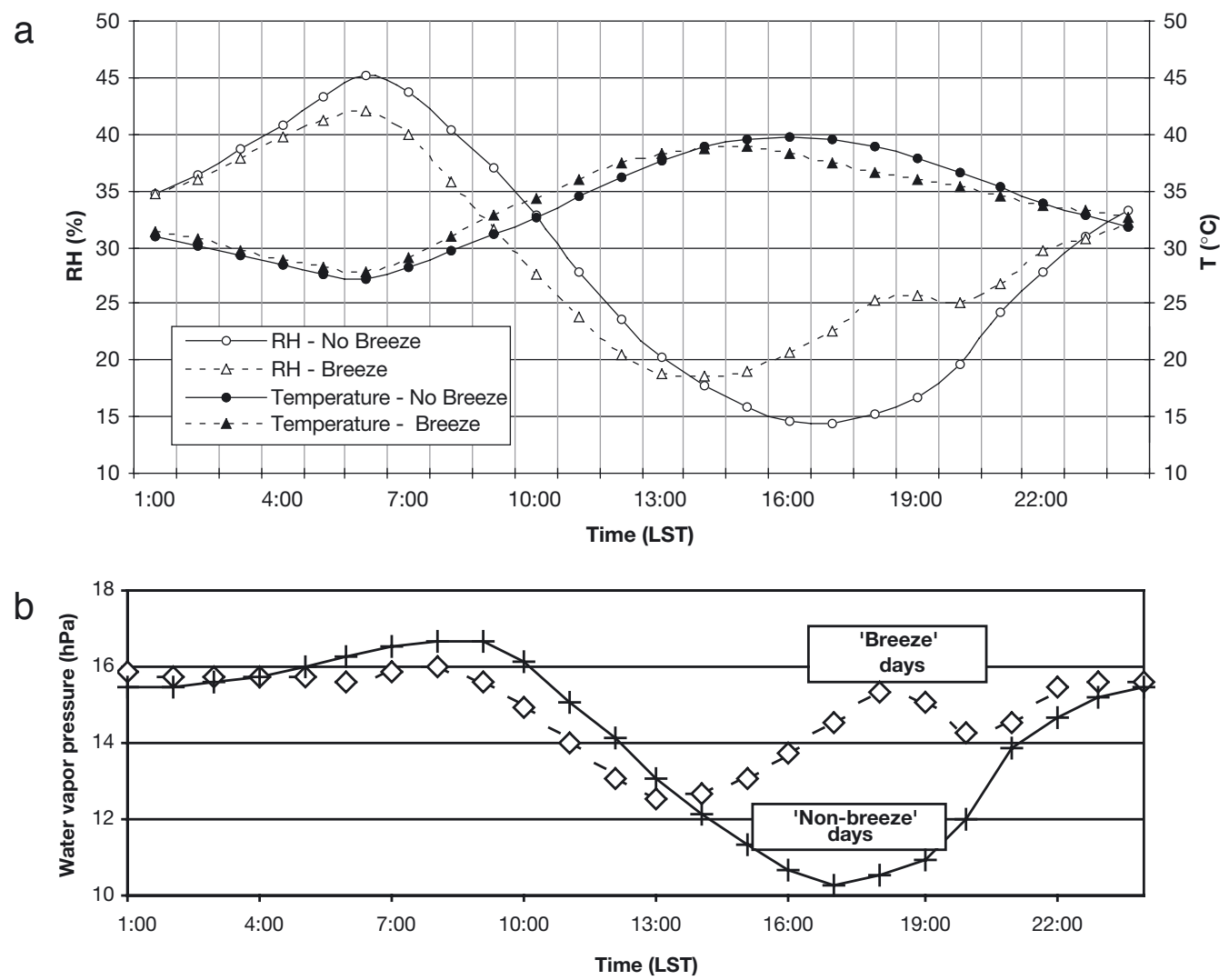

Fig. 8. Diurnal variation in (a) temperature ( $T$ ) and relative humidity (RH) and (b) water vapor pressure for 'breeze' days (dashed lines) and 'non-breeze' days (solid lines) for the years 1996-1999

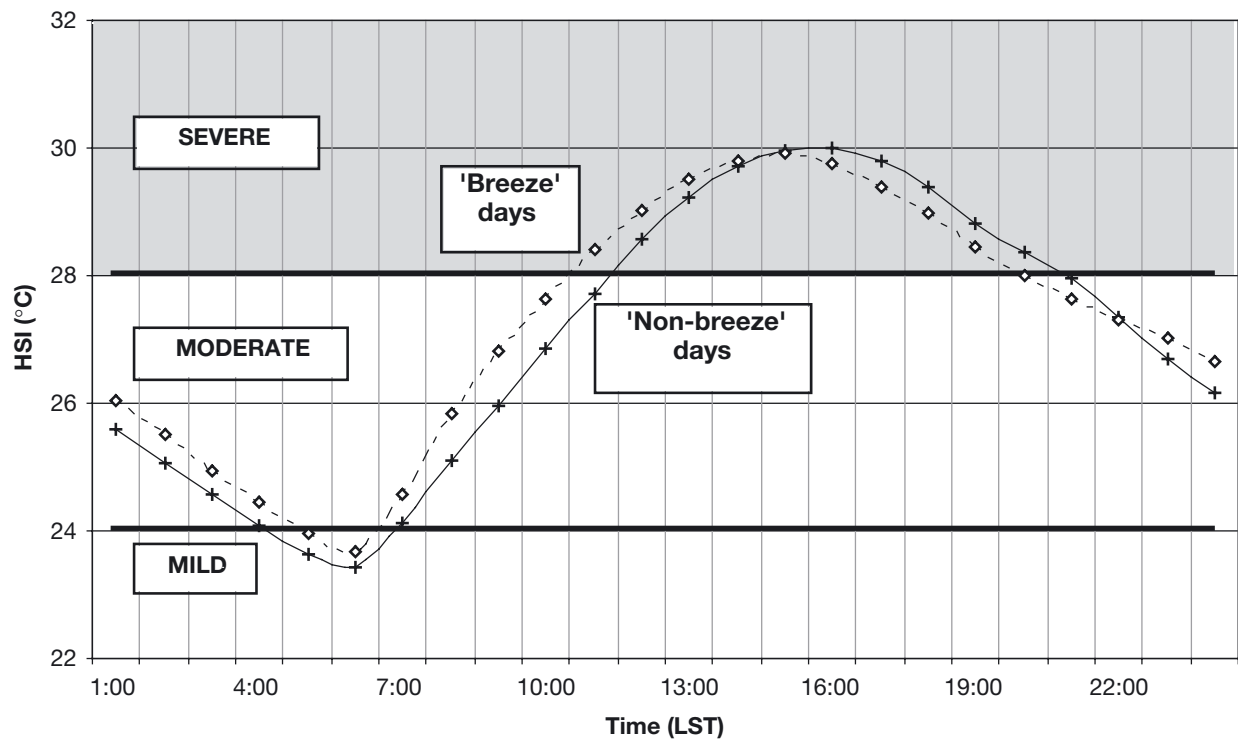

Fig. 9. Diurnal variation in heat stress (HSI) for 'breeze' days (dashed line) and for 'non-breeze' days (solid line) for the years 1996-1999 


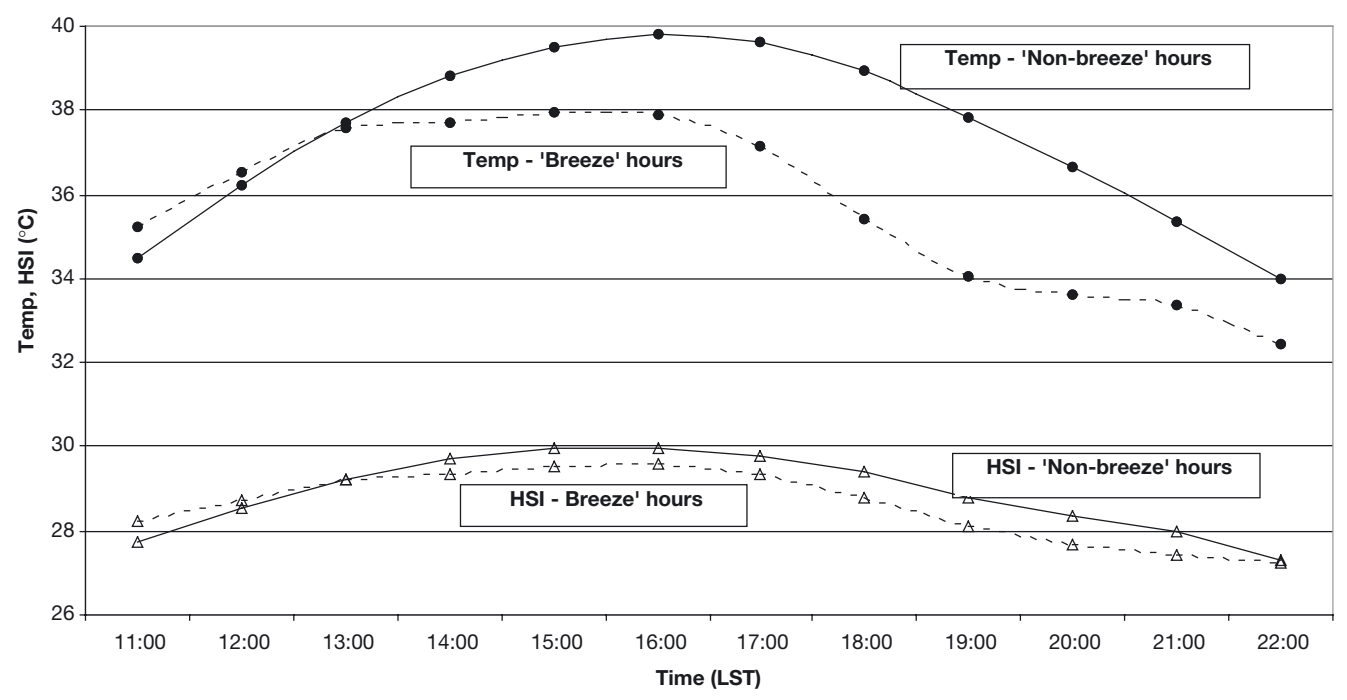

Fig. 10. Variation in temperature and HSI (Heat Stress Index) during the midday and afternoon hours for the days when at a given hour southerly wind (sea breeze) was observed (dashed lines) and for the remaining days (solid lines). The period was chosen so that for each hour at least 10 cases of southerly winds were observed. $\bullet$ : temperature; $\Delta$ : heat stress

that, in spite of its small size, the Gulf of Eilat is an effective source of sea breeze. Therefore, the cause for the weak signature of sea breeze in Eilat is the suppressive synoptic forcing.

The role of the synoptic factor in controlling the breeze is represented by the regional northwestsoutheast pressure gradient, which was 38\% weaker on the 'breeze' days compared to the rest of the days. The synoptic seasonal increase in the pressure gradient along July and August also explains the seasonal decrease in the frequency of 'breeze' days, together with the seasonal decrease in solar radiation. The seasonal trend is also expressed by the fact that the $10 \mathrm{~d}$ on which the sea breeze lasted for $12 \mathrm{~h}$ or more were observed only in July, 9 of them on the first $20 \mathrm{~d}$ of the month. It can be concluded that when synoptic forcing suppresses the sea breeze under severe arid conditions the magnitude of the sea breeze is highly dependent on the synoptic scale pressure gradient.

The 'breeze' days were found to be hotter and drier at night and during the morning hours than the 'nonbreeze' days. No corresponding temperature difference was found at the $850 \mathrm{hPa}$ level, indicating that synoptic-scale warming is not the cause for this difference. This difference may be explained by the role of turbulence, which diffuses heat and moisture from the surface upward. Accordingly, the stronger winds on the 'non-breeze' days (Fig. 5) produce more turbulence. This can explain the lower temperature, but not the higher water vapor pressure, found on these days. Moreover, since turbulence is effective in reducing temperature only during the daytime, when the nearsurface lapse rate is super-adiabatic, the lower temper- atures which are also observed during nighttime emphasize that another factor is involved. This additional factor is the advective effect of the northerly winds, which transport cooler and moister air originating from the EM (Fig. 1). So, the stronger northerly winds during the 'non-breeze' days explain the relatively moist and cool conditions observed on these days. This agrees with Segal et al. (1985) and Alpert \& Getenio (1988), who found that the sea breeze, originating from the Mediterranean, reaches the southern part of the Rift Valley in the evening hours.

The temperature and relative humidity difference between 'breeze' and 'non-breeze' days is reversed in the afternoon hours. The relieving effect of the sea breeze, expressed in the heat stress difference, is only $0.4^{\circ} \mathrm{C}$. But if the higher heat stress observed on the 'breeze' days prior to the breeze initiation (by $0.8^{\circ} \mathrm{C}$ between 9:00 and 11:00 h LST) is considered, the effect of the breeze becomes more pronounced, $\sim 1.2^{\circ} \mathrm{C}$. A comparison of the average heat stress, observed each hour and averaged separately for the days on which a southerly wind blew at that hour and the remaining days (Fig. 10), showed the relieving effect to be $1.5^{\circ} \mathrm{C}$. Since the heat stress is severe for $10 \mathrm{~h}$ a day in both groups of days, the relieving effect of the sea breeze is rather small.

It is worth noting that the average duration of severe heat stress for the study period 1996 to 1999, i.e. $10 \mathrm{~h}$, is $3 \mathrm{~h}$ longer than for the 1963 to 1983 period (Bitan \& Rubin 1994). This finding is consistent with the difference in the average 14:00 h LST temperatures, which are $0.5^{\circ} \mathrm{C}$ higher in our study period. This difference can be explained by the increase in the urban heat island and by the regional warming trend observed 
during these months in the second half of the 1990s (Saaroni et al. 2003).

The wind speed also has an important relieving effect (Givoni 1991). The lower speed of the sea breeze, with respect to the prevailing northerly winds, implies that the subjective sensation on 'breeze' days may be even worse. Another important factor in Eilat concerns the cooling system of homes, the 'desert coolers', which cool the indoor air by evaporating water, the efficiency of which depends on the difference between dry and wet bulb temperatures. Since this difference is reduced due to the sea breeze by several degrees (up to $6^{\circ} \mathrm{C}$ during the late afternoon), the breeze hours are expected to become more oppressive in houses where this cooling device is used.

Our results can be applied to other coastal regions where severe heat stress is combined with offshore prevailing winds. Therefore, in order to identify coastal regions having these specifications, we searched the entire globe, using the NCEP/NCAR archive. The chosen threshold temperature for representing severe heat stress was an air temperature of $25^{\circ} \mathrm{C}$ at the $925 \mathrm{hPa}$ level (daily average). We retrieved several coastal regions that met the above criteria; for January, representing the southern hemispheric summer, the coastal region of Namibia (around 20 to $25^{\circ} \mathrm{S}$ ) and the western coast of Australia (20 to $30^{\circ} \mathrm{S}$ ) and for July, representing the northern hemispheric summer, the coast of Mauritania (around $20^{\circ} \mathrm{N}$ ) and southern Iraq.

Acknowledgements. This study is supported by the Israeli Science Foundation (ISF, grant no. 828/02). Special thanks are due to O. Zafrir-Reuven for drawing Fig. 2.

\section{LITERATURE CITED}

Air Ministry Meteorological Office (1962) Weather in the Mediterranean, 1. Air Ministry Meteorological Office, London

Alpert P, Getenio B (1988) One-level modeling for diagnosing surface winds over complex terrain. Part I. Comparison with 3-D modeling in Israel. Mon Wea Rev 116:2025-2046

Alpert P, Cohen A, Neumann J, Doron E (1982) A model simulation of the summer circulation from the Eastern Mediterranean past Lake Kinneret in the Jordan Valley. Mon Wea Rev 110:994-1006

Alpert P, Abramsky R, Neeman BU (1990) The prevailing summer synoptic system in Israel-subtropical high, not Persian trough. Isr J Earth Sci 39:93-102

Arrit RW (1993) Effects of large scale flow on characteristic features of the sea breeze. J Appl Meteorol 32:116-125

Arya SP (2001) Introduction to micrometeorology. Academic Press, San Diego

Bitan A (1977) The influence of the special shape of the Dead
Sea and its environment on the local wind system. Arch Meteorol Geophys Bioklimatol Ser B 24:283-301

Bitan A (1981) Sea and land breeze around Lake Kinneret. Isr Meteorol Res Pap 3:123-144

Bitan A, Rubin S (1994) Climatic atlas of Israel for physical and environmental planning and design. Ramot Publishing, Tel Aviv

Bitan A, Saaroni H (1992) The horizontal and vertical extension of the Persian Gulf pressure trough. Int J Climatol 12: 733-747

Doron E, Newmann J (1977) Land and mountain breezes with special attention to Israel Mediterranean coastal plain. Isr Meteorol Res Pap 1:109-122

Givoni B (1991) Impact of planted areas on urban environmental quality: a review. Atmos Environ 25B: 289-299

Goldreich Y, Druyan LM, Berger H (1986) The interaction of valley/mountain winds with a diurnally veering sea/land breeze. J Climatol 6:551-561

Kalnay E, Kanamitsu M, Kistler R, Collins W and 18 others (1996) The NCEP/NCAR 40-year reanalysis project. Bull Am Meteorol Soc 77:437-471

Kistler R, Kalnay E, Collins W, Saha S and 9 others (2001) The NCEP/NCAR 50-year reanalysis: Monthly means CD-ROM and documentation. Bull Am Meteorol Soc 82:247-267

Laird NF, Kristovich DAR, Liang XZ, Arritt RW, Labas K (2001) Lake Michigan lake breezes: climatology, local forcing, and synoptic environment. J Appl Meteorol 40(3): 409-424

Mahrer Y (1985) A numerical study of the effects of sea surface temperature on the sea land breeze circulation. Isr J Earth Sci 34:91-95

Melas D (2000) An investigation of the boundary layer dynamics of Sardinia Island under sea breeze condition. J Appl Meteorol 39(4): 516-524

Melas D, Ziomas IC, Zerefos CS (1995) Boundary layer dynamics in an urban coastal environment under sea breeze condition. Atmos Environ 29(24): 3605-3617

Metaxas DA (1977) The interannual variability of the Etesian frequency as a response of atmospheric circulation anomalies. Bull Hell Meteorol Soc 2:30-40

Oke TR (1987) Boundary layer climates. Methuen, London

Prezerakos NG (1984) Does the extension of the Azores anticyclone towards the Balkans really exist. Arch Meteorol Geophys Bioklimatol Ser A 33:217-227

Saaroni H, Ziv B (2000) Summer rainfall in a Mediterranean climate-the case of Israel: climatological-dynamical analysis. Int J Climatol 20:191-209

Saaroni H, Ziv B, Edelson J, Alpert P (2003) Long-term variations in summer temperatures over the Eastern Mediterranean. Geophys Res Lett 30(18):CLM 8-1-8-4 1946 doi: 10.1029/2003GLO17742

Segal M, Mahrer Y, Pielke RA, Kessler RC (1985) Model simulation of the summer daytime induced flows over southern Israel. Isr J Earth Sci 34:39-46

Skibin D, Hod A (1979) Subjective analysis of mesoscale flow patterns in Northern Israel. J Appl Meteorol 18:329-338

Sohar E (1980) Determination and presentation of heat load in physiologically and meaningful terms. Int J Bioclimat B 14: 336-359

Thom EC (1959) The discomfort index. WeatherWise 12: $57-60$

Zhong S, Takle ES (1993) The effect of large-scale winds on the sea-land breeze circulation in an area of complex coastal heating. J Appl Meteorol 32:1181-1195

Submitted: August 22, 2003; Accepted: May 6, 2004

Proofs received from author(s): 